\title{
Political behavior in organizational context: nature, research and paradigm
}

\author{
Hasan Jafariani $^{\mathrm{a}^{*}}$, Saeed Mortazavi ${ }^{\mathrm{b}}$, Shamsodin Nazemi ${ }^{\mathrm{c}}$ and Peter Bull ${ }^{\mathrm{d}}$
}

${ }^{a}$ Ph.D Student of organizational behaviour at Ferdowsi University of Mashhad, Iran

${ }^{b}$ Associate professor of organizational behaviour at Ferdowsi University of Mashhad, Iran.

${ }^{c}$ Associate professor of strategic management at Ferdowsi University of Mashhad, Iran

${ }^{d}$ Department of psychology, York University, England

\begin{tabular}{l}
\hline A R T I C L E I N F O \\
\hline Article history: \\
Received June 28, 2012 \\
Received in Revised form \\
August, 26, 2012 \\
Accepted 29 August 2012 \\
Available online \\
9 September 2012 \\
\hline Keywords: \\
Organizational politics \\
Political behavior \\
Perception of organizational \\
behavior \\
Political skill
\end{tabular}

A B S T R A C T

\begin{abstract}
This paper investigates political behavior in organization context. In the first section, it studies inappropriate terminology in political behavior arena and recommends that political behaviors are neither positive nor negative in nature. The study also demonstrates that ends and means for influencing others are two criteria for determining faces of political behavior. In the second section, related and important research are reviewed and categorized in terms of content. Finally, we present the dominant paradigm of political behavior as a philosophical infrastructure. The study also presents some guidelines for further research the limitations are discussed in conclusion part.
\end{abstract}

C) 2012 Growing Science Ltd. All rights reserved.

\section{Introduction}

It is clear that natural behaviors occur in organizations as social phenomena. Good or bad, positive or negative behaviors in organizations always exist and whatever scholars need to study is the "social reality". According to Schein (1977) "one reality of organizational life consists of rational behaviors involving planning, organizing, directing and controlling. Underlying these activities is another set of organizational behaviors resolving around the gaining and keeping of power, the consideration and understandings of such behavior have been the focus of disciplines attached to the political arena, most notably political science."

Viewing organizations as political entities is not something new, March (1962), for instance, recommended that organizations were political coalitions in which decisions could be made and goals

* Corresponding author

E-mail addresses: h.jafariani@gmail.com (H. Jafariani) 
could be set by bargaining processes. Other writers stressed the utility of taking a political perspective when studying organizations (Mayes \& Allen, 1977). One of the issues in organizational politics is conflict of interest (Pfeffer, 1981). Miles (1980), for instance, found that political activities could happen when there are vague objectives, scarce resources, changes in technology or environment, non-programmed decisions, etc. Anyone associated with almost any type of organization eventually knows about activities explained by employees as "political", but what is expressed political by someone could not be considered as political by another person. To understand the nature of political processes in business units, some people believe that constitutes of political behavior need to be developed (Mayes \& Allen, 1977).

During the past few years, there has been growing interests in political behavior within organizations (Atnic et al., 2010). However, since there are some difficulties in studying political behavior, this topic has kept under some more investigations to resolve different aspects and ambiguities, for instance, Mintzberg (1977) is one of the early people who described political behaviors in his great article as "Policy as a field of management theory".

One of these ambiguities or probably the most vital aspects is the duality in nature of political behaviors. In spite of many studies, there is no clear definition on whether political behavior is useful or not. In other words, it is not clear that whether managers and employees should utilize these behaviors or not. We are also interested in finding the dominant paradigm of political behavior.

In the next section, we study the terminology of political behavior and after reviewing two faces of political behavior, we attempt to categorize related studies in a noble way. In the last section we presented a philosophical discussion to determine dominant paradigm of political behavior.

\section{Inappropriate terminology: toward a definition of political behavior}

One of the issues in management literature is inappropriate terminology. The first question is to know what organizational politics, political behaviors mean, and what are the main differences between these two concepts. The absence of common definitions for organization politics and political behavior is a long-standing concern, and commentators continued to note the lack of agreement (Drory \& Romm, 1990; Ferris et al., 2002). Kacmar and Carlson (1997) argued that 'Only when consensus is reached about what organizational politics is and how it should be measured will the field be advanced'. Points of contention concern distinguishing 'political' from 'non-political' actions, the treatment of self-interest as a defining characteristic, and the inevitably damaging nature of politics (Buchanan, 2008). Therefore, it is necessary to accurately define "organizational politics" and "political behaviors". We first review definitions of organizational politics and then present definitions of political behaviors and finally discuss about differences of these two concepts. There are many definitions of organizational politics as follow:

1- "Organizational politics involves those activities taken within organizations to acquire, develop, and use power and other resources to obtain one's preferred outcomes" (Pfeffer 1981).

2- "Organizational politics is the management of influence to obtain ends not sanctioned by the organization or to obtain sanctioned ends through non-sanctioned means" (Mayes \& Allen 1977).

3- Organizational politics are "those actions not officially approved by an organization taken to influence others to meet one's personal goals" (Greenberg \& Baron, 1997) and would appear to be inevitable in organizational life (Curtis, 2003).

4- Allen et al. (1979) define politics as 'acts of influence to enhance or protect the self-interest of individuals or groups'. 
There are also some other definitions about political behavior as follow:

1- "Political behavior in organizations may be defined as those activities that are not required as part of one's organizational role but that influence, or attempt to influence, the distribution of advantages and disadvantages within the organization" (Farrell \& Paterson 1982).

2- "Behaviors geared toward influencing by creating the impression that the individual conforms to the machine-like performance standards valued by the organization" (Ferris \& King 1991).

3- Valle and Perrewe' (2000) stated political behavior as 'the exercise of tactical influence which is strategically goal directed, rational, conscious and intended to promote self-interest, either at the expense of or in support of others' interests'.

4- Political skill is defined as: 'The ability to effectively understand others at work and to use such knowledge to influence others to act in ways that enhance one's personal and/or organizational objectives' (Ferris et al., 2005).

5- Mintzberg (1977, 1983, 1985) defines politics as 'individual or group behavior that is informal, ostensibly parochial, typically divisive, and above all, in the technical sense, illegitimate - sanctioned neither by formal authority, accepted ideology, nor certified expertise'.

As Buchanan and Badham (2008) stated, there are some problems with the definition features involving influence and self-interest. First, as Mangham (1979) and Astley and Sachdeva (1984) observed, all routine social exchanges entail mutual influence, and every interaction could thus be interpreted as being political. An influence-based definition, therefore, does not readily distinguish a political from a non-political behavior. Indeed, attribution theory explains that it is necessary for managers to prevent having their actions labeled with political intent, and it may be necessary to create the impression that goals are selfless and non-political. Successful manipulation may be that which attracts attributions of legitimate motives (Allen et al., 1979) that combines social astuteness with the ability to relate well, and otherwise demonstrate situational suitable behavior in a disarmingly charming and engaging manner that inspires confidence, sincerity, trust and genuineness'. Ferris et al. (2002) explained that skilled political actors are those who are able to disguise their self-serving intent (Buchanan, 2008).

A second problem is that political tactics can be used to promote either or both individual and organizational interests (Buchanan, 1999; Harrison, 1987). If political tactics creates corporate advantage as well as personal gain, then definitions that regard only overtly self-interested act as categorically political would not be beneficial (Buchanan, 2008). Unfortunately, as we can observe in the above-mentioned definitions, there is an inappropriate definition for political behavior and organizational politics or even policies. Many people examined different aspects of political behavior and organizational politics without paying attention to the difference between terms; they used "organizational politics" but they meant "political behaviors" While there is some implicit, if not explicit, assumption that the two constructs are related (Harrell-cook et al., 1998). The present work views political behavior and organizational politics as distinct and separate constructs in terms of domain and function.

According to definitions, organizational politics is a wider construct than political behavior. Organizational politics maintains three levels of individual, group and organizational levels. These politics are imposed by organization not individual while in political behavior, individual is considered and politics imposed by that individual not organization. Therefore, the very first difference between organizational politics and political behavior is that an organizational politic comes from organization while a political behavior comes from individuals. 
The second difference is that organizational politics are shaped by goals, norms, values, beliefs, experience and strategies of founders or managers of organizations in a long period of organization's life whereas political behaviors have cognitive roots and appears through time. The third difference between organizational politics and political behaviors is that organizational politics are reflected in forms of administrative mechanisms and rules. While political behaviors are not rules they are behaviors that go beyond contracts and sometimes cover the legal gaps. There is no rule or principle for influencing the others.

Abdollatif et al. (2011) demonstrated the forth difference. "Political behaviors in terms of organizational context may be defined as facilitating the non-rational influence on decision making and existing as a "back-stage" doings. On the other hand, definitions of organizational politics focus on the exercise of power, the manipulation of influence". The last but not the least difference between organizational politics and political behavior is described in terms of macro and micro where the domain of organizational politics can be considered as macro but political behavior is more stated as micro.

Organizational politic is related to different things such as actions, process and activities, which are harder and they are external to political intents but political behavior is associated with individual behaviors and usually is implemented in communications and interactions among people. In other words, people in workplace follow their interests by political behaviors because these behaviors result in imposing impact. Although, this conflict happens in management context but because this paper tries to explore concept of political behaviors, researches that have used organizational politics as political behavior is considered with their own words.

\section{The two faces of political behaviors}

Organization politics is a controversial topic. Managers' advises on how to become better organizational politicians may not be widely regarded as legitimate activities. Klein (1988) argues that the claim that organizations are political is 'a myth propagated and entertained to address various needs of organizational members'. Accepting this makes it self-perpetuating, and consequently political behavior should be eliminated instead.

Political behavior presents positive and negative, 'nice and nasty' faces to the observer and to recipients or victims. As most management behaviors, organization politics can have dual impacts including benefits and costs. We will argue, however, that not all 'tricks' are 'dirty tricks', and an adequate assessment must explore both dimensions (Buchanan \& Badham, 2008 ). Although political behavior normally maintain both positive and negative consequences, more studies are concentrated on "dark side" (Ferris \& King, 1991) political behaviors and characterized by self-interest.

A wider understanding of political behavior may thus be an advantage to those who would deploy such strategies and tactics, and, at the same time, supports those who look for challenge and counter such behaviors (Buchanan \& Badham, 2008 ). Ferris et al. (2007) stated "The organizational-politics literature, frequently cast in a pejorative sense, has begun to recognize that politics are not necessarily inherently bad and those who engage in influence do not always do so exclusively in a self-interested manner and in direct opposition to organizational objectives". Furthermore, political behavior in organizations recently has been highlighted against a societal background of decreasing trust in authority and by an increase in journalistic revelations of wrongdoing (Farrell \& Peterson, 1982).

This discussion can be continued forward without having any useful conclusions. Pattern of Mays and Allen (1982) seems to be suitable framework for leading to result the challenge. Myes and allen (1982) believed that OP is a dynamic process of impact, which produces organizationally associated outcomes beyond the simple performance of job tasks. Common organizational practice is to include each member of the organization with a description of duties, which specifies the organizationally desired job outcome and the limits of discretionary behavior acceptable in attaining those outcomes. 
Thus, the existing organization delineates both acceptable outcomes and appropriate means to their attainment for each job position.

The approach of this authors represented in Table 1. Quadrant I, characterized by organizationally specified job/behavior, is the only non-political quadrant in the classification system. Quadrant II contains political activities recognized by some bureaucratic theorists as abuses of formal authority/ power . Behavior in this quadrant is dysfunctional from the standpoint of the organization, in that organizational resources are being utilized to further non-organizational objectives. The bureaucratic form of organization can be viewed as an attempt to eliminate this type of behavior.

Quadrant III defines political behavior undertaken to accomplish legitimate organizational objectives. The use of charisma or side-payments to accomplish sanctioned objectives would be included in behaviors assigned to this quadrant.

Quadrant III activity could be functional to the organization if undesirable side-effects did not occur. Indeed, some writers view organizationally functional Quadrant III behavior as leadership.

Quadrant IV behavior, like Quadrant II behavior, is dysfunctional from the organizational perspective. It deviates from organization norms with respect to both outcomes and methods.

\section{Table 1}

Kinds of behavior in organizations

\begin{tabular}{lll}
\hline \multirow{2}{*}{$\begin{array}{l}\text { Influence } \\
\text { Means }\end{array}$} & $\begin{array}{l}\text { Organizationally } \\
\text { Sanctioned }\end{array}$ & Not Sanctioned by Organization \\
\hline $\begin{array}{l}\text { Organizationally } \\
\text { Sanctioned }\end{array}$ & $\begin{array}{l}\text { Non-Political } \\
\text { I Job Behavior }\end{array}$ & $\begin{array}{l}\text { Organizationally Dysfunctional } \\
\text { II Political Behavior }\end{array}$ \\
\hline $\begin{array}{ll}\text { Not Sanctioned by } \\
\text { Organization }\end{array}$ & $\begin{array}{l}\text { Political Behavior } \\
\text { Ill Potentially Functional to the }\end{array}$ & $\begin{array}{l}\text { Political Behavior } \\
\text { IV Organizationally Dysfunctional }\end{array}$ \\
\hline
\end{tabular}

We can see that political behavior is not positive or negative in its nature. However, it is an inactive phenomenon like science, power and many other social phenomena. Like whatever Mays and Allen (1977) found out, ends and means are two important criteria for labeling a behavior as legitimate or illegitimate. If a political behavior takes place with legitimate ends and means, that behavior is legitimate, can be developed and might impact positively in human interactions. However, when political behaviors happen with illegitimate ends and means or both of them, that behavior is illegitimate. Since ends can be individual or collective and they are interrelated, identification of wrong or right might be difficult. This complexity also exists for means because they might be tangible or intangible. Therefore, moving in frame of ethical codes has a double importance for the holder of the behavior. If we accept ethics as a relative concept, which is deeply rooted in religion and culture, we should say that in diverse cultures, political behaviors may occur in many different forms. This relativism would result in this proposition:

Legitimate political behaviors in one culture are not necessarily legitimate in another and all of these discussions show that complexities of political behaviors are increasable.

\section{Political behavior: Research review}

The topic of organizational politics has been the subject of much casual conversation in the work place (Gandz \& Murray, 1980), and it is increasingly becoming the focus of empirical research (Drory \& Romm,1990; Ferris \& Kacmar, 1992; Ferris et al., 1996; Ferris et al., 1994b; HarrellCook et al., 1999; Parker et al., 1995). Much of the research in the field of organizational politics 
has taken a decidedly top-down approach, emphasizing environmental and structural variables to explain politics in organizations (Gandz \& Murray, 1980; Madison et al., 1980; Pfeffer, 1981). These studies have approached the topic of politics from a macro perspective. This perspective derives from a broader, systems approach (Cyert \& March, 1963), which emphasizes interdependence and the exercise of departmental power (Bacharach \& Lawler, 1981; Kipnis, 1976; Lawler \& Bacharach, 1983; Pettigrew, 1973; Tushman, 1977). Others have suggested studying political actions from the point of view of the individual - a micro perspective (Burns, 1961; Farrell \& Petersen, 1982; Porter et al., 1981; Vredenburgh \& Maurer, 1984).

While researchers have recognized the importance of individual political behaviors in organizations (Burns, 1961; Frost \& Hayes, 1977; Pettigrew, 1973; Tushman, 1977), understanding the conceptual underpinnings as well as the consequences of individual political behavior are also considered by (Schein, 1977; Valle \& Perewe, 2000). Political behavior is suited in micro level and the business and popular press have advanced political characterizations of managerial behavior in organizations, which depict the self-interested manager of today as a decidedly different breed of animal than the "organization man" of the 1950s portrayed by Whyte (1956). Indeed, the "organization man" manager is believed to have taken a back seat to a variety of political creatures who roam the corridors of corporate America, including Hirsch's (1987) "Free- Agent Manager," Maccoby's (1978) "Gamesman," Kelly’s (1988) "Destructive Achiever," Kanter and Mirvis's (1989) "Articulate Player," and Ferris et al. (1991) "Organizational Chameleon."

Sofer (1970) appeared to characterize Ferris et al. (1991) "Organizational Chameleon" when he stated: "It is said that the would-be successful executive learns when to simulate enthusiasm, compassion, interest, concern, modesty, confidence, and mastery, when to smile, with whom to laugh, and how intimate to be with others. If the operation succeeds, one will have fabricated a personality in harmony with his environment". Similarly, Jackal (1988) discussed successful managers as "those who learn to streamline oneself shamelessly, learn to wear all the right masks, learn all the right vocabularies of discourse, get to know all the right people, and cultivate the subtleties of the art of self-promotion" (Valle \& Perewe, 2000).

Most important research in field of political behaviors exhibited in Table 2. Earlier studies and in special form before 1976 are studies whose main topic is not political behavior. However, they attempt to answer questions like these: what do managers really do? How can a manager be effective? What are the competencies of successful managers Research as shown in the Table 2, In terms of content and methodologies are divided in to two categories: American school and German school.

\section{American school}

Most of the published papers prior to year 2000 are theoretical papers, which uses inductive logics and have developed concepts, models and most of these studies were conducted, and they were published in United States. Therefore, we can call them American school. Researchers of this school are at Florida State University or Mississippi University. This type of studies and approaches for investigation of political behavior are typical and logical. The concept of political behavior is still under review and study and scientists try to develop theories and to determine domain and scope of this concept. Their results are interesting as Mintzberg (1976) says: the variables in this field have diversity and studying of this concept has many complexities. This school has own attributions. They are focused on content and process.

Researches in this category have two sub-categories. Some of them studied pure political behavior and others focused on perceptions on political behaviors. They believe political behavior are as important as political behavior in pure form. The first category attempted to develop political behavior concept and dimensions. 


\section{Table 2}

Most important research

\begin{tabular}{|c|c|c|}
\hline Author(s) & Method & Results \\
\hline $\begin{array}{l}\text { Mintzberg, } \\
1977\end{array}$ & TR & $\begin{array}{l}\text { To be relevant, policy research must be softer and encompass a richer array of variables than in other } \\
\text { fields of management. Management policy should be taught from the perspective of descriptive theory. }\end{array}$ \\
\hline $\begin{array}{l}\text { Schein, } \\
1976\end{array}$ & TR & $\begin{array}{l}\text { This discussion focuses on individual power related behaviors. A conceptual scheme links: (a) the bases } \\
\text { of individual power; (b) the intent of the power holder; and (c) the means of the power holder. }\end{array}$ \\
\hline $\begin{array}{l}\text { Bronston } \\
\text { et al., } \\
1977\end{array}$ & TR & $\begin{array}{l}\text { Organizational politics is the management of influence to obtain ends not sanctioned by the } \\
\text { organization or to obtain sanctioned ends through non-sanctioned influence means. }\end{array}$ \\
\hline $\begin{array}{l}\text { Farrell \& } \\
\text { Petersen, } \\
1982\end{array}$ & TR & $\begin{array}{l}\text { The need for a concern for individual political behavior is explored, and three key dimensions of } \\
\text { political behavior are suggested: internal-external, vertical-lateral, and legitimate-illegitimate. A } \\
\text { typology based on these dimensions is proposed, and predictions about the different types of political } \\
\text { behavior are offered. }\end{array}$ \\
\hline $\begin{array}{l}\text { Ryan, } \\
1989\end{array}$ & TR & $\begin{array}{l}\text { Main intention is to suggest some ideas about political behavior which will help people to take effective } \\
\text { action within their organizational context. }\end{array}$ \\
\hline $\begin{array}{l}\text { Judge \& } \\
\text { Bretz, Jr, } \\
1994\end{array}$ & HR & $\begin{array}{l}\text { Results from a sample of past graduates of two universities indicated that supervisor-focused tactics, } \\
\text { manifesting a strategy of ingratiation, resulted in higher levels of career success while job-focused } \\
\text { tactics, manifesting a strategy of self-promotion, resulted in lower levels of success. }\end{array}$ \\
\hline $\begin{array}{l}\text { Ferris, et } \\
\text { al., } 1994\end{array}$ & TR & $\begin{array}{l}\text { They strive to improve upon and extend previous attempts by developing a political conceptualization } \\
\text { of managerial behavior that incorporates several disciplinary perspectives, and has implications for } \\
\text { human resources systems. }\end{array}$ \\
\hline $\begin{array}{l}\text { Harrell- } \\
\text { cook et al., } \\
1999\end{array}$ & RA & $\begin{array}{l}\text { Hypotheses were supported for the proposed relationships between self-promotion and two of the work } \\
\text { outcomes: satisfaction with supervision and intent to leave. Significant effects were also found for } \\
\text { ingratiation; however, they were opposite to those proposed for the perceptions of organizational } \\
\text { politics intent to leave relationship. }\end{array}$ \\
\hline $\begin{array}{l}\text { Cohen } \\
\& V i d a d a, \\
1999\end{array}$ & HR & Political behavior is related to important behaviors and attitudes in the work setting. \\
\hline $\begin{array}{l}\text { Valle \& } \\
\text { Perrewe, } \\
2000\end{array}$ & RA & $\begin{array}{l}\text { Use of reactive/defensive political behaviors exacerbated the already negative effects of perceived } \\
\text { organizational politics on outcomes. Further; the set of variables that come from the job/work } \\
\text { environment were found to explain more variance in perceptions of organizational politics than the } \\
\text { set of organizational or individual variables. Finally. Perceptions of politics demonstrated mediation } \\
\text { effects between the antecedent variables and job satisfaction, job anxiety and intent to turnover. }\end{array}$ \\
\hline $\begin{array}{l}\text { Ferris et } \\
\text { al., } 2005\end{array}$ & SEM & $\begin{array}{l}\text { Political skill was positively related to self-monitoring, political savvy and emotional intelligence; } \\
\text { negatively related to trait anxiety; and not correlated with general mental ability. Also, the PSI predicted } \\
\text { performance ratings of managers in two samples. }\end{array}$ \\
\hline $\begin{array}{l}\text { Buchanan } \\
, 2008\end{array}$ & $\mathrm{CIO}$ & $\begin{array}{l}\text { Most managers viewed political behavior as ethical and necessary, and aspects of organizational } \\
\text { effectiveness, change, resourcing and reputation were attributed to political tactics, although } 80 \% \text { had } \\
\text { no training in this area. }\end{array}$ \\
\hline
\end{tabular}

\begin{tabular}{lll}
\hline $\begin{array}{l}\text { Atinc et } \\
\text { al., } 2010\end{array}$ & MA & $\begin{array}{l}\text { The results suggest specific courses of action that organizations might take to reduce the perceptions of } \\
\text { organizational politics and its deleterious effects. }\end{array}$ \\
\hline $\begin{array}{l}\text { Blickle \& } \\
\text { Schnitzler, } \\
2010\end{array}$ & SEM & $\begin{array}{l}\text { The PSI did not correlate with social desirability, but it correlated positively with extraversion, } \\
\text { conscientiousness, and income, and negatively with neuroticism, thus demonstrating construct and } \\
\text { incremental criterion-related validity under both conditions. }\end{array}$ \\
\hline $\begin{array}{l}\text { Wei et al., } \\
2010\end{array}$ & SEM & $\begin{array}{l}\text { They found that supervisor-subordinate Guanxi mediated the relationship between political skill and } \\
\text { career development of the subordinates. }\end{array}$ \\
\hline $\begin{array}{l}\text { Blickle et } \\
\text { al., 2011 }\end{array}$ & HR & $\begin{array}{l}\text { The results demonstrated significant predictive effects of political skill (i.e. beyond age, sex, education } \\
\text { level, tenure on the job, and experience in sales) on all four measures of sales performance }\end{array}$ \\
\hline $\begin{array}{l}\text { Blickle et } \\
\text { al., 2011 }\end{array}$ & HR & $\begin{array}{l}\text { The results provided strong and consistent support for the hypotheses, thus providing a more direct test } \\
\text { of socio-analytic theory and extending it to demonstrate effects beyond overall job performance ratings } \\
\text { on contextual performance and promotion ability assessments. }\end{array}$ \\
\hline
\end{tabular}

The results demonstrated that political skills accounted for a significant proportion of job performance al., 2011 HR (i.e., using a 1-year timeframe) in the second study examined effects on multiple dimensions of job performance.

\begin{tabular}{ll}
\hline $\begin{array}{l}\text { Blickle et } \\
\text { al., } 2011\end{array}$ HR & $\begin{array}{l}\text { Reputation mediated the relationships between political skill, hierarchical position, and career } \\
\text { satisfaction. }\end{array}$ \\
\hline $\begin{array}{l}\text { TR: Regression analysis HR: Hierarchical regression, SEM: structural equation models, CIO: constructivist-interpretive orientation, RA: regression } \\
\text { analysis, MA: Meta analysis }\end{array}$
\end{tabular}


Ferris (1994) believed while the issue of managerial political behavior continues to receive increased attention, the greatest stumbling block, both theoretically and empirically may be the need for a more precise notion of what constitutes. Pfeffer (1981) argued for a political perspective on organizations. He called for research, which would develop a more informed understanding of the political construct in organizations. Mintzberg (1983) suggested that political skill referred to the exercise of influence through persuasion, manipulation, and negotiation.

The second category is based on perceptions of political behavior. Research on organizational politics has largely focused on perceptions of organizational politics. Some people suggest that people act based on their perceptions of reality rather than objective reality (Ferris et al., 2002). Indeed, there is some empirical evidence suggesting that perceived reality is the most important factor in determining workers' attitudes and behavior (Breaux et al., 2009).

Perceived organizational politics “involves an individual's attribution of behaviors of self-serving intent and is defined as an individual's subjective evaluation about the extent in which the work environment is characterized by co-workers and supervisors who demonstrate such self-serving behavior" (Ferris et al., 2000). Perceived organizational politics sometimes casts as a "hindrance" or threatening form of stressor in that it constrains an individual's belief in their ability to achieve personal and professional goals (Chang et al., 2009; Lepine et al., 2005). Recent meta-analytic reviews provide strong evidence supporting the view that perceptions of organizational politics are related to reduced job satisfaction, organizational commitment, citizenship behavior, task performance and increased psychological strain (Chang et al., 2009; Miller et al., 2008).

As we have seen, these researches are functional and have associated with perceptions of political behavior on variables like effectiveness, performance, career success and promotions. For instance, Valle and Perewe (2000) concluded that perceptions of politics demonstrated mediation effects among antecedent variables and job satisfaction, job anxiety and intent to turnover. Ferris et al. (1989) suggested that there were at least three potential responses to perceptions of a politically charged organizational environment: employees may withdraw from the organization; they may remain a member of the organization but not become involved in the politics; or they may stay with the organization and attempt to engage them in the political activity. Based on this distinction, employees who perceive the organization as politically charged often view it as stressful, ambiguous, and frustrating. Those who have decided to stay and engage in politics may do so in an effort to gain some degree of control over the organizational environment.

\section{German school}

Since year 2000, there have been tremendous efforts on behalf of researchers in Germany, which have contributed significantly on implementations of quantitative methods. This category with focus on political skill tries to relate the political skills to other psychological and behavioral variables, empirically. Most research in this school are affected by political skill inventory (PSI). Once PSI was conducted in USA, and its reliability was verified, different scholars started using this technique for their studies. According to Blickle et al. (2011), political skill is a recently developed interpersonal competency construct, which has been stated as "the ability to effectively understand others at work and to use such knowledge to influence others to act in ways that enhance one's personal and/or organizational objectives" (Ferris et al., 2005). Political skill combines social understanding with the ability to adjust behavior to the demands of the situation in different including inspire trust, confidence, support, appear genuine, and effectively influences others (Ferris et al., 2005, 2007).

Politically skilled people possess social competencies, which enhance their personal and/or organizational goals through their understanding and influence others in social interactions at work. The social astuteness of politically skilled individuals provides them with a keen awareness every 
one, which gives the capacity to calibrate and adjusts behavior to various and changing contexts. Such astuteness and contextual adaptability permits politically skilled individuals to do a great deal of interpersonal impacts since many influential attempts are not perceived, properly (Blickle et al., 2011). Political skill enables individuals to calibrate and to adapt their behaviors. It also influences various contextual demands, indicating politically skilled individuals should be able to manage a broad variety of people with divergent interests in a manner, which inspires consistent and positive evaluations from multiple assessors. Political skill has been shown to emerge as the best predictor of managerial job performance when examined in competitive prediction with other social effectiveness constructs (Semadar et al., 2006), and superior to self-efficacy in the prediction of contextual job performance (Jawahar et al., 2008).

Political skill has emerged as a significant predictor of overall job performance ratings after controlling for general mental ability and the Big Five personality characteristics, both crosssectionally and predicatively (Blickle et al., 2011b; Liu et al., 2007). Furthermore, political skill was found to predict early employees' subsequent income level, hierarchical position, and career satisfaction (Ferris et al., 2008; Todd et al., 2009). Although these researches and their findings are interesting but they are not very reliable because the studies in the American school have defendable and logical trends. Once the concept was introduced, the variables in this culture were identified and models and constructions have emerged, while in Germany we do not see this logical trend. They examined and used PSI before localizing basic concept of political behavior and skill. When results from one organization can be different from another in the same culture, findings, definitions, and attitudes about this concept in another country can be consequently different.

\section{Dominant paradigm of political behavior Ontology}

There are many definitions for ontology and a clear example of one category of definitions is the theory or the study of objects and their relationships. Although this definition seems very intuitive and easy to understand, it is flawed in its drawing into an ontological assumption of objects being presented. An operational definition not associated with objects is that ontology is a specification of a conceptualization (Foucault, 1975). The fact that this definition also needs to be coupled by the definition of conceptualization makes it clear that defining what is ontology is a very hard task. The ontology seems to be the answer to this question: what is out there? (Göktürk, 2011). To investigate the reality in terms of scholars of political behavior, "Word stemming" is essential to the political behavior.

Most prominent scholars of political behavior have adhered to this assumption for developing the concept of this field. As noted in the research background, developed concept in this area, emphasized on being perceptual and mentality. On the other hand, as mentioned before, researches on organizational politics have largely concentrated on perceptions of organizational politics. Lewin (1936) suggested that individuals act based on their perceptions of reality rather than objective reality (Ferris et al., 2002). These comments and others similar ones prove that reality in field of political behavior is not objective. Therefore, according to those philosophical assumptions, which divide reality into subjective or objective, political behavior views realities from a subjective viewpoint.

These discussions lead us to ontology of constructivism, where the subject has no direct access to external reality and can only develop knowledge by using cognitive principles to organize experience. If we take this notion of creating knowledge of reality based on human mind and imagination, what we see as reality is just our perception from the perceived world. This synthesis of Kant supports the view that it is impossible to reach purely objective representations of things. Thus, constructivism does not necessarily accept objectivism, which embraces the belief that a human being can come to know external reality. It holds the opposite view that the only reality we can know is what is 
represented in and by human thought. Therefore, there is subjectivity in knowing the external reality (Upadhyay, 2009).

\section{Methodology}

The variable and personal (intermental) nature of social constructions suggests that individual constructions can be elicited and refined only through interaction beween and among investigator and respondents. These varying constructions are interpreted using conventional hermeneutical methods, and they are compared and constracted through a dialictical interchange. The final objective is to distill a concensus construction, which is more informed and sophisticated than any of the predecessor construction (Goba \& linkoln, 1994).

\section{Epistemology}

Epistemology investigates the relationship between the known and unknown issues. In the positivist paradigm, the object of study depends on researchers; knowledge is discovered and verified through direct observations; facts are built by taking apart a phenomenon to investigate its component parts. An alternative view, the naturalist or constructivist view is that knowledge is built through the meanings attached to the phenomena studied; researchers interact with the subjects of study to obtained data; inquiry changes both researcher and subject; and knowledge is a speical context, which is time dependent (Coll et al., 2002). Since political behavior is a social construct and a subjective concept investigator and reality are interrelated. Inexistence of comprehensive theories about political behavior and diversion in variables, which could impact on political perceptions, shows that epistemology of political behavior is transactional like constructivism. In constructivism also the investigator and the object of investigation are assumed to be interactively linked so that the findings are literally created as the investigation proceeds.

\section{Discussions and directions for future researches}

The results of this paper serve to further our understanding of the complexities involved in relation to political behavior meaning, good or bad nature of political behavior and research directions and philosophical foundations of political behavior. We showed that political behavior is not synonemous with organizational politics and there are explicite differences among them in terms of origins, functions, forms of appearance and domain.

We indicated that taking good or bad orientations in relation to political behavior is an old challenge but has remained up to date whereas means and ends have introduced as suitable ceriteria for judging about being wrong or right. In terms of this paper, although this problem is important but scholars should go beyond of this situation. It is better to investigate how managers behave politically and how gentel should we treat the authors who think that these issues are more important than previous challenges. Investigating when, how, and why bad or good political behavior arise, can be helpful for the development of this concep in the correct route. Finally, philosophical fundations of political behavior emphasize on the role of methods, questions and instruments and scholars as important parts of reseach which should be consistent with constructivism paradigm in this context.

\section{Practitioner points}

Although this article is a critical review, but has some important point for practitioners:

1- Political behaviors are problematic not only in theory but also in practice. So, it is necessary for practitioners to use these behaviors with more accuracy and intelligence. When a managers use political behavior, in reality, he/she plays political roles. If intent and aim of 
these roles were detected by employees, managers could seem as black actors and their behavior would seem full funny, and resistance to change would appear.

2- Illegitimate political behavior must never appear especially by managers. If this takes place, It will be the starting point for the escape of rules and the abnormality in organizations.

\section{References}

Allen, R. W., Madison, D. L., Porter, L. W., Renwick, P. A., \& Mayes, B. T. (1979). Organizational politics: tactics and characteristics of its actors. California Management Review, 22 (1), 77-83.

Astley, W. G., \& Sachdeva, P. S. (1984). Structural sources of intraorganizational power: a theoretical synthesis. Academy of Management Review, 9 (1), 104-113.

Atinc, G., Darrat, M., Parker, B., \& Fuller, B. (2010). Perceptions of organizational politics: A metaanalysis of theoretical antecedents. Journal of Managerial Issues, 21, 119-139.

Bacharach, S. B., \& Lawler, E. J. (1981). Power and politics in organizations: The social psychology of conflict, coalitions, and bargaining. San Francisco, CA: Jossey-Bass.

Blickle, G., \& Schnitzler, A. (2010). Is the Political Skill Inventory Fit for Personnel Selection? An Experimental Field Study. International Journal of Selection and Assessment,18, 155-165.

Blickle, G., Fröhlich, J. Ehlert, S., Pirner, K, Dietl, E., Hanes T. J., \& Ferris, G. R. (2011). Socioanalytic theory and work behavior: Roles of work values and political skill in job performance and promotability assessment. Journal of Vocational Behavior, 78, 136-148.

Blickle, G., Kramer, J., Schneider, P.B., Meurs, J.A., Ferris, G.R.,Mierke, J., Witzki, A.H., \& Momm, T.D. (2011). Role of political skill in job performance prediction beyond general mental ability and personality in cross-sectional and predictive studies. Journal of Applied Social Psychology, 41, 239-265.

Blickle, G., Schneider, P. B., Liu, Y., \& Ferris, G. R. (2011). A predictive investigation of reputation as mediator of the political skill - career success relationships. Journal of Applied Social Psychology, 41, 3026-3048.

Blickle, G., Wendel, S., \& Ferris, G.R. (2010). Political skill as moderator of personality-job performance relationships in socioanalytic theory: Test of the getting ahead motive in automobile sales. Journal of Vocational Behavior, 76, 326-335.

Breaux, D. M., Munyon, T. P. Hochwarter, W. A., \& Ferris, G. R. (2009). Politics as a Moderator of the Accountability-Job Satisfaction Relationship: Evidence across Three Studies. Journal of Management, 35, 307-326.

Buchanan, D., \& Badham, R (2008). Power, Politics, and Organizational Change: winning the turf game. Sage, London.

Burns, T. (1962). Micro politics: Mechanisms of organizational change. Administrative Science Quarterly, 6, 257-281.

Chang, C. H., Rosen, C. C., \& Levy, P. E. (2009). The Relationship between Perceptions of Politics and Employee Attitudes, Strain, and Behavior: A Meta-analytic Examination. Academy of Management Journal, 52, 779-801.

Cohen, A., \& Vigoda, E. (1999). Politics and the workplace: An empirical examination of the relationship between political behaviour and work outcomes. Public Productivity Management Review, 22(3), 389-406.

Coll, R. K., \& Chapman, R. (2000). Choices of methodology for cooperative education researchers. Asia-Pacific Journal of Cooperative Education, 1, 1-8.

Cousins, C. (2002). Getting to the "truth": Issues in contemporary qualitative research. Australian Journal of Adult Learning, 42, 192-204.

Cyert, R.M. \& March, J.G. (1963). A Behavioural theory of the firm. Englewood Cliffs, NJ: PrenticeHall. 
Curtis, S. (2003). Lies, damned lies and organizational politics. Industrial and Commercial Training, 35(7), 293-297.

Drory, A., \& Romm, T. (1988). Politics in organization and its perception within the organization. Organization Studies, 9 (2), 165-179.

Farrell, D., \& Patterson, J. C. (1982). Patterns of political behavior in organizations. Academy of Management Review, 7, 403-412.

Ferris, G.R., Blickle, G., Schneider, P.B., Kramer, J., Zettler, I., Solga, J., Noethen, D., \& Meurs, J.A. (2008). Political skill construct and criterion-related validation: A two-study investigation. Journal of Managerial Psychology, 23, 744-771.

Ferris, G. R., \& Kacmar, K. M. (1992). Perceptions of Organizational Politics. Journal of Management, 18, 93-116.

Ferris, G. R., \& King, T. R. (1991). Politics in Human Resources Decisions: A Walk on the Dark Side. Organizational Dynamics, 20, 59-71.

Ferris, G. R., Anthony, W. P., Kolodinsky, R., Gilmore, D. C., \& Harvey, M. G. (2002). Development of political skill. In Wankel, C. and DeFillippi, R. (Eds), Research in Management Education and Development, Rethinking Management Education for the 21st Century. Greenwich, CT: Information Age Publishing, 3, 3-25.

Ferris, G. R., Frink, D. D., Galang, M. C., Zhou, J., Kacmar, M., \& Howard, J. L. (1996). Perceptions of organizational politics: prediction, stress-related implications, and outcomes. Human Relations, 49 (2), 233-266.

Ferris, G. R., Russ, G. S., \& Fandt, P. M. (1989). Politics in Organizations. Pp. 143-170 in Impression Management in the Organization, edited by R. A. Giacalone and P. Rosenfeld. Hillsdale, NJ: Lawrence Erlbaum.

Ferris, G. R., Judge, T. A., Rowland, K. M., \& Fitzgibbons, D. E. (1994). Subordinate influence and the performance evaluation process: Test of a Model. Organizational Behavior and Human Decision Processes, 58, 101-135.

Ferris, G. R., Fedor, D. B., \& King, T. R. (1994). A political conceptualization of managerial behavior. Human Resource Management Review, 4, 1-34.

Ferris, G.R., Treadway, D.C., Kolodinsky, R.W., Hochwarter, W.A., Kacmar, C.J., Douglas, C., \& Frink, D.D. (2005). Development and validation of the political skill inventory. Journal of Management, 31, 126-152.

Ferris, G.R., Treadway, D.C., Perrewé, P.L., Brouer, R.L., Douglas, C., \& Lux, S. (2007). Political skill in organizations. Journal of Management, 33, 290-320.

Frost, P.I. \& Hayes, D.C. (1977). An exploration in two cultures of political behavior in organizations. Paper presented at the Conference on Cross Cultural Studies in Organizational Functioning, Hawaii.

Gandz, J. and Murray, V. V. (1980). The experience of workplace politics. Academy of Management Journal 23: 237-251.

Göktürk, E. (2011). What is Paradigm? Department of Informatics, University of Oslo, Norway, is available as of January 2, 2011: http://folk.uio.no/erek/essays/paradigm.pdf

Greenberg, J., \& Baron, R.A. (1997). Behavior in organizations, 6 ed. Englewood Cliffs, NJ: Prentice-Hall.

Guba, E. G., \& Lincoln, Y. S. (1994). Competing paradigms in qualitative research. In N. K. Denzin \& Y. S. Lincoln (Eds.), Handbook of qualitative research (pp. 105-117). Thousand Oaks, CA: Sage.

Harman, W. W. (1970). An incomplete guide to the future. New York: W. W. Norton.

Harrell-Cook, G., Ferris, G. R., \& Dulebohn, J. H. (1999). Political behaviors as moderators of the perceptions of organizational politics-work outcomes relationships. Journal of Organizational Behavior, 20 (7), 1093-1105.

Harrison, E. F. (1987). The Management Decision-Making Process. Boston, MA: Houghton Mifflin. Hirsch, P. (1987). Pack Your Own Parachute. Reading, MA: Addison-Wesley. 
Jackall, R. (1988). Moral Mazes: The World of Corporate Managers. New York: Oxford University Press.

Jawahar, I.M., Meurs, J.A., Ferris, G.R., \& Hochwarter, W.A. (2008). Self-efficacy and political skill as comparative predictors of task and contextual performance: A two-study constructive replication. Human Performance, 21, 138-157.

Kacmar, K. M., \& Carlson, D. S. (1997). Further validation of the perceptions of politics scale (POPS): a multiple sample investigation. Journal of Management, 23 (5), 627-658.

Kacmar, K. M., \& Ferris, G. R. (1991). Perceptions of organizational politics scale (POPS): development and construct validation. Educational and Psychological Measurement, 51(1), 193205.

kanter, D. L., \& Mirvis, P. H. (1989). The Cynical Americans: Living and Working in an Age of Discontent and Disillusion. San Francisco: Jossey-Bass.

Kelly, C. M. (1988). The Destructive Achiever: Power and Ethics in the American Corporation. Reading, MA: Addison-Wesley.

Kipnis, D. (1976). The power holders. Chicago, IL: The University of Chicago Press.

Kuhn, T. S. (1970). The Structure of Scientific Revolutions. revised edition. Chicago: The University of Chicago Press.

Lawler, E. J., \& Bacharach, S. B. (1983). Political action and alignments in organizations. In S. B. Bacharach (ed.), Research in the sociology of organizations, 2, 83-107. Greenwich, CT: JAI Press.

Lepine, J. A.,. Podsakoff, N. P., \& Lepine, M. A. (2005). A Meta-Analytic Test of the Challenge Stressor-Hindrance Stressor Framework: An Explanation for Inconsistent Relationships among Stressors and Performance. Academy of Management Journal, 48 (5), 764-775.

Lewin, K. (1936). Principles of Topological Psychology. New York: McGraw-Hill.

Liu, Y., Ferris, G.R., Zinko, R., Perrewé, P.L., Weitz, B., \& Xu, J. (2007). Dispositional antecedents and outcomes of political skill in organizations: A four-study investigation with convergence. Journal of Vocational Behavior, 71, 146-165.

Luthans, F. (1988). Successful vs. effective real managers. Academy of Management Executive, 11, 127-132.

Maccoby, M. (1978). The Gamesman. New York: Bantam Books

Madison, D. L., Allen, R. W., Porter, L. W., Renwick, P. A. \& Mayes, B. T. (1980). Organizational politics: An exploration of managers perceptions. Human Relations, 33, 79-100.

Mangham, I. (1979). The Politics of Organizational Change. Westport, CT: Greenwood Press.

March, J. G. (1962). The Business Firm as a Political Coalition. Journal of Politics, 24, 662-678.

Mayes, B. T., \& Allen, R. W. (1977). Toward a Definition of Organization Politics. Academy of Management Review, 2, 672-678.

Miles, R. H. (1980). Macro organizational behavior. Santa Monica, Cal.: Goodyear Publishing

Miller, B. K., \& Nichols, K. M. (2008). Politics and Justice: A Mediated Moderation Model. Journal of Managerial Issues, 20, 214-237.

Mintzberg, H. (1983). Power in and around Organizations. Upper Saddle River, NJ: Prentice Hall.

Mintzberg, H. (1985). The organization as political arena. Journal of Management Studies, 22, 133154.

Minzberg, H. (1977). Policy as a Field of Management Theory. Academy of management review 2(1), 88-103.

Parker, C.P., Dipboye, R.L. \& Jackson, S.L. (1995). Perceptions of organizational politics: An investigation of antecedents and consequences. Journal of Management. 21, 891-912.

Pettigrew, A. M. (1973). The Politics of Organizational Decision-making. London: Tavistock.

Pfeffer, J. (1981). Power in organizations. Boston: Pitman.

Porter, L. W., Allen, R. W., \& Angle, H. L. (1981). The politics of upward influence in organizations. In L. L. Cummings \& B. M. Staw (Eds.), Research in organizational behavior. 3, Greenwich, Conn.: JAI Press. 
Ritzer, G. (1975). Sociology: A Multi-paradigm Science. Boston: Allyn \& Bacon, Inc.

Ryan, M. (1989). Political behavior and management development. Management Education and Development, 20, 238-253.

Schein, V.E (1977). Individual power and political behaviours in organizations: an inadequately explored reality. Academy of management review, 2, 64-72.

Sederberg, P. C. (1984). The Politics of Meaning: Power and Explanation in the Construction of Social Reality. Tucson, AZ: University of Arizona Press.

Semadar, A., Robins, G., \& Ferris, G.R. (2006). Comparing the effects of multiple social effectiveness constructs on managerial performance. Journal of Organizational Behavior, 27, 443-461.

Todd, S.Y., Harris, K.J., Harris, R.B., \& Wheeler, A.R. (2009). Career success implications of political skill. Journal of Social Psychology, 149, 179-204.

Tushman, M. L. (1977). A political approach to organizations: A review and rationale. Academy of Management Review, 2, 206-216.

Upadhyay. B. (2010). Science, religion, and constructivism: constructing and understanding reality. Cultural Studies of Science Education Journal, 5, 41-46.

Valle, M., \& Perrewe, P. L. (2000). Do politics perceptions relate to political behaviours?: tests of an implicit assumption and expanded model. Human Relations, 53(3), 359-386.

Vredenburgh, D.J. \& Maurer, J.G. (1984). A process framework of organizational politics. Human Relations, 37, 47-66.

Wei. L, Liu. J, Chen. Y., \& Wu. L. Z. (2010). Political Skill, Supervisor-Subordinate Guanxi and Career Prospects in Chinese Firms. Journal of Management Studies. 47(3), 437-454.

Whyte, W. H., Jr. (1956). The Organization Man. New York: Simon and Schuster. 